\title{
FLASH-FLOODING OF EPHEMERAL STREAMS IN THE CONTEXT OF CLIMATE CHANGE
}

\author{
ANA M. CAMARASA-BELMONTE \\ Department of Geography, University of Valencia, \\ Avda. Blasco Ibañez, 28. 46010 Valencia, Spain.
}

\begin{abstract}
Ephemeral streams, which are more extended than expected, entail a significant flood risk. Historically they have been underestimated due to their intermittent flow and the lack of knowledge on their hydrogeomorphology. Currently, European legislation recognizes their associated risk and supports research into them, adapting the scale and methodology to their characteristics. Based on the compilation of various works carried out in four Valencian catchments (Eastern Spain), this paper approaches the key questions of rainfall-runoff conversion and flood generation in ephemeral streams, taking into account their hydro-geomorphological specificity. Moreover, the consequences which derive from current environmental changes are addressed in the wider scale of Júcar River Water Authority.
\end{abstract}

The study is based on 5-minute data, registered by the SAIH-Júcar network (Authomatic Hydrological Information System). The investigation has been conducted in two phases. Firstly, key issues determining flash-flood generation at basin scale have been addressed, based on the study of 138 floods, registered between 1989 and 2018, in four Valencian ephemeral streams (Barranc del Carraixet, Rambla de Poyo, Riu Vernissa and Rambla de Gallinera). Secondly, concerning a broader scale (Júcar River Water Authority), the evolution of 698 rain episodes (1989-2007) has been analysed. Finally, the consequences that environmental changes (climatic, anthropogenic and morphogenetic) might mean for flash-flood generation have been discussed.

The results show how environmental changes point towards an increase in risk to the detriment of resource. Rain episodes tend to increase in intensity and decrease accumulated precipitation. As a consequence, hydrological connectivity will become more dependent on rain intensity, thus reducing runoff thresholds and basin response times. Anthropic changes enhance this behaviour, reducing infiltration and increasing surface runoff and erosion, while accelerating the hydrological cycle. An increase in process-form disequilibrium in Mediterranean catchments can be expected due to the increase in morphogenetic phases (because of the intensification of events) and a decrease in the efficiency of low-magnitude recovery episodes.

Consequently, the behaviour of ephemeral-streams under current climate change conditions points firstly to an increase in intense flash-flood events, which will be difficult to manage with the current flood control measures, and secondly an increase in the general aridity conditions of catchments.

\section{Las avenidas súbitas en ramblas en un contexto de cambio climático}

RESUMEN. Las ramblas mediterráneas, más extendidas espacialmente de lo que pudiera parecer, implican un riesgo de inundación significativo, históricamente subestimado debido a su flujo intermitente y al desconocimiento generalizado sobre su funcionamiento hidrogeomorfológico. Actualmente, sin embargo, la legislación europea reconoce la especificidad de estos sistemas, así como el riesgo que entrañan y aboga por profundizar en su conocimiento, adaptando la escala y la metodología a sus particularidades. Basado en la recopilación de varios 
trabajos realizados sobre la zona de estudio, el presente artículo aborda cuestiones clave de la conversión lluviacaudal y generación de crecidas en ramblas, así como su evolución en el contexto actual de cambio ambiental.

El estudio se basa en datos originales cincominutales, registrados por la red SAIH-Júcar (Sistema de información hidrológica automática) y se realizó en dos fases. En primer lugar, se abordaron cuestiones clave que determinan la generación de crecidas a escala de cuenca, a partir de 138 eventos, registrados entre 1989 y 2018, en cuatro ramblas valencianas (Barranc del Carraixet, Rambla de Poyo, Riu Vernissa y Rambla de Gallinera). En segundo lugar, a una escala más general, se ha analizado la evolución de 698 episodios de lluvia en el territorio de la Demarcación Hidrográfica del Júcar, entre 1989 y 2016, con objeto de inferir qué consecuencias podrían suponer los cambios ambientales para la formación de inundaciones en ramblas. Los resultados muestran cómo estos cambios sugieren aumento del riesgo y disminución del recurso. Los episodios tienden a aumentar su intensidad y a disminuir la precipitación acumulada. Como consecuencia, la conectividad hidrológica se vuelve cada vez más dependiente de la intensidad de la lluvia, reduciendo así los umbrales de escorrentía y los tiempos de respuesta de la cuenca. Los cambios antrópicos potencian este efecto, porque reducen la infiltración y aumentan la escorrentía superficial y la erosión, al tiempo que aceleran el ciclo hidrológico. Por tanto, se anuncia un aumento en el desequilibrio proceso-forma debido al aumento de las fases morfogenéticas (por intensificación de los eventos) y a una disminución en la eficiencia de los episodios restauradores de baja magnitud. En consecuencia, el comportamiento de las ramblas bajo condiciones de cambio climático apunta, en primer lugar, hacia un incremento de las flash-floods intensas, cada vez más difíciles de gestionar con los instrumentos habituales de control de avenidas y, en segundo lugar, hacia una progresiva aridificación de estas cuencas mediterráneas.

Key words: intermittent rivers, environmental change, Mediterranean, inundation, risk.

Palabras clave: ríos intermitentes, cambio ambiental, Mediterráneo, inundación, riesgo.

Received: 8 August 2020

Accepted: 4 November 2020

Corresponding author: A. M. Camarasa-Belmonte, Department of Geography, University of Valencia, Avda. Blasco Ibañez, 28, 46010-Valencia (Spain).E-mail: ana.camarasa@uv.es

\section{Introduction}

Ephemeral streams are more frequent than assumed since, globally, more than $50 \%$ of the river network is intermittent (Skoulikidis et al., 2017). In the case of Europe, the Mediterranean strip is the most affected, with percentages that can vary from $20 \%$ in the case of France (Snelder, 2013) to more than $90 \%$ in Sardinia and Sicily (Petrakis et al., 2012). Gómez et al. (2005) estimate that more than 70\% of fluvial systems are ephemeral streams in the south-east of Spain. An increase in this percentage is to be expected over the next century, because as a consequence of climate change, drylands are predicted to expand approximately by $10 \%$ before the 22 nd century (Feng and $\mathrm{Fu}, 2013$ ).

In the Mediterranean region, ephemeral streams exhibit certain climatic, geomorphological and anthropic characteristics which condition the hydro-geomorphological processes of runoff generation. Climatically, seasonal rainfall regime is very irregular as it is subject to severe summer droughts and autumn episodes of high intensity (Camarasa-Belmonte and Soriano, 2014). From the geomorphological point of view, basins are small and steep with permeable lithology and wide channels (hydrologically disconnected from the aquifers). Headwater used to be covered by species adapted to water stress and poorly developed soils (Gómez et al., 2005). However, floodplains are very fertile and have suffered from intense human occupation for over 8000 years (Butzer, 2005). Regardless, the Mediterranean 
environment, often described as highly degraded, has been able to develop strong ecological and human resilience to degradation (Butzer, 2005).

However, the current important changes, both environmental and anthropic, are threatening the precarious balance between water resources and flood risk (Barredo and Engelen, 2010; Durán et al., 2014; Camarasa et al., 2020). On the one hand, climate change on a global scale has accelerated the hydrological cycle with the result that episodes of catastrophic floods have increased and intensified (Olcina et al., 2017). On a regional scale, according to all indicators (European Environment Agency, 2019), the Mediterranean region will suffer the greatest impact in Europe, since it is a transitional area which is more exposed to extreme events. On the other hand, on a basin scale, changes in land use are affecting the ephemeral stream environments, in particular due to the degradation of headwaters as well as the indiscriminate occupation of floodplains (Canton et al., 2011; Calsamiglia et al., 2018). Flood risk is exponentially increasing but, paradoxically, this fact is being underestimated because of the intermittence of flow.

The estimation and adaptation to flood risk in ephemeral streams, under a context of climate change, goes through two phases: firstly, understanding and recognizing the specificity of Mediterranean hydrology (as a morphoclimatic transition between humid and arid environments) and secondly, analyzing what may be the reaction of these fluvial systems to the evolution of intense rainfall episodes.

The first part requires focusing the analysis on empirical flash flood case studies (Shannon et al., 2002), which is not easy given the lack of sufficient and detailed hydrological information (Zoccatelli et al., 2019). The lack of flow data is partly due to the low economic interest that ephemeral streams have long generated. Precisely due to their intermittency they have not been considered as a water resource. Furthermore, even in the case of the availability of information, data were of poor quality and not sufficiently detailed regarding flash-flood times. The information was generally recorded every day, whereas a sub-daily time scale (hourly or even minute scale) was needed in order not to mask the processes (Camarasa-Belmonte, 2016).

However, this situation regarding the lack of knowledge has begun to change. This change has been driven by the European legislative framework (EU Floods Directive2007/60/EC), which recognizes the significant risk caused by flash-floods generated in intermittent Mediterranean ephemeral streams. Thus, the hydrological specificity of these fluvial systems is highlighted, as well as the need for developing methodology and to adjust data set to small catchment scale. In this sense, it is worth noting the effort made in recent years by the scientific community to analyse cases of flash flooding and associated risks. The second part, related to the evolution of these floods under the climate change conditions, is currently crucial for Spain because, as stated in the report on Floods and Climate Change prepared by the Ministry for Ecology Transition (2018), "an increase in flash floods in most of the basins in Spain has been observed" (MINECO, 2018).

The present study addresses both phases: that of flash flood generation, and its trend under the current context of climate change in a wide area of the Spanish Mediterranean coast. This paper is based on previous studies carried out in the territory of Jucar River Authority from detailed data provided every five minutes by the Automatic Hydrological Information System (SAIH) network. The investigation was conducted in two phases and addressed two work scales.

The first part of the study approaches the key issues of flash-flood generation in ephemeral streams, based on the analysis of 138 events registered in four gauged pilot sub-basins (ranging from 25 to $185 \mathrm{~km}^{2}$ ) from 1989 to 2018 . During the second phase, a more general scale of study has been addressed, concerning the entire territory of Jucar Water Authority $\left(42,989 \mathrm{~km}^{2}\right)$. Climate, anthropic and geomorphic changes have been described in order to analyse how trends in environmental changes can affect flash-floods. In summary, this research aims to provide a dynamic framework to integrate 
both scales, those of basin and climate, as well as their interaction under conditions of environmental change.

\section{Study area}

The study area involves two spatial scales: (i) the basin scale, to study flood hydrology processes in ephemeral streams, and (ii) a more general scale, to frame the evolution of environmental changes (Fig. 1).

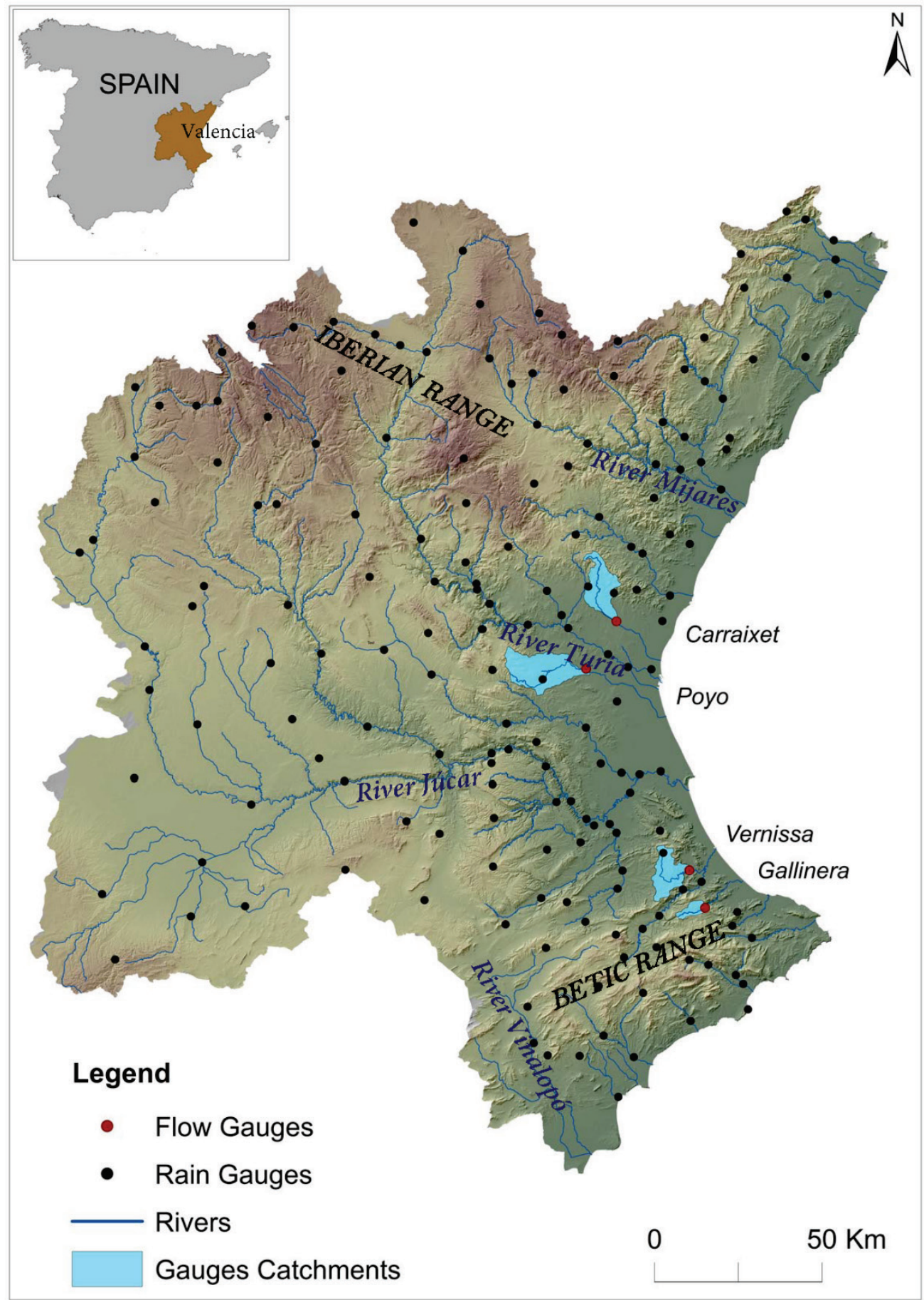

Figure 1. Study area. 
The basin scale includes four Valencian ephemeral streams, monitored by the SAIH network. The hydrological analysis was carried out in the gauged sub-basins of the following watersheds: Barranc del Carraixet; Rambla de Poyo; Rambla de Gallinera and Riu Vernissa, whose main characteristics are listed in Table 1. Areas range from $27 \mathrm{Km}^{2}$ in Gallinera (gauged at headwater) to $187 \mathrm{~km}^{2}$ in Poyo. Slope of catchments is high, varying from $33 \%$ in Gallinera to $17 \%$ in Poyo. Runoff thresholds, also known as initial abstraction, have been calculated from the physical features of the basin according to the SCS method (1972), which was adapted to Spain by Témez (1978). The average threshold for pilot catchments is $64 \mathrm{~mm}$ (from 56 to $72 \mathrm{~mm}$ ).

Table 1. Gauged sub-basins features.

\begin{tabular}{|c|c|c|c|}
\hline Catchment & Surface $\left(\mathrm{km}^{2}\right)$ & Slope $(\%)$ & Initial abstraction $(\mathrm{mm})$ \\
\hline Carraixet & 125 & 21 & 70.8 \\
\hline Poyo & 185 & 17 & 57.8 \\
\hline Gallinera & 27 & 33 & 56.6 \\
\hline Vernissa & 102 & 25 & 72 \\
\hline
\end{tabular}

The broader scale involves the territory of Júcar Water Authority $\left(42,989 \mathrm{~km}^{2}\right)$, in the east of Spain. The climate is typical Mediterranean, with $500 \mathrm{~mm}$ of average annual precipitation (from 800 $\mathrm{mm}$ in the north to $300 \mathrm{~mm}$ in the south). Intense rainfall episodes concentrate in autumn-winter and spring.

The study area is quite heterogeneous and shows a marked inland-coast dichotomy. Inland is mountainous and includes the headwaters whereas on the coast, flood-plain and other sedimentary forms have been developed. Regarding extreme episode distribution, intense rainfall in the littoral is five times higher than inland (Morrell and Pérez-Cueva, 2000). Camarasa-Belmonte and Soriano (2014), using 5min detailed data, checked that higher rainfall intensities were registered close to the sea, whereas lower rainfall intensities affected the inland area. From a human perspective, water resources are generated and stored inland (where dams and broad aquifers are located) while flood risks are expected on the coast (where larger urban centres are placed).

\section{Methods and materials}

Several studies of both topics, the generation of floods in ephemeral streams (CamarasaBelmonte, 2016) and trends in rain episodes (Estrela et al., 2016; Marcos-García and Pulido-Velázquez, 2017; Camarasa-Belmonte et al., 2020), have been carried out in the study area. This paper combines the main results previously obtained by Camarasa-Belmonte with new analysis of recent episodes to illustrate the key issues of flash-floods. The aim is to discuss how ephemeral streams could behave under the current trend in climate change.

Original data were recorded by the SAIH network every five minutes from 147 rain gauges and 4 streamflow (one in each pilot catchment) between 1989 and 2018. For the hydrological study at catchment scale, 137 flash-flood events were analysed (16 in Carraixet, 38 in Poyo, 38 in Gallinera and 45 in Vernissa) between 1989 and 2007 (Camarasa-Belmonte, 2016). A multi-peak flood event (October 2018 in Vernissa) has been added to the study. The events were selected because the data were reliably collected and they covered a representative range of floods including the most damaging.

The following hydrological indicators have been estimated for each flood event (using data provided by 16 rain-gauges and 4 stream-gauges, which covered sub-basins):

a) Spatial averaged rainfall inputs (Thiessen polygons were used to average point data):

- Hyetograph of areal intensity $(\mathrm{mm} / \mathrm{h})$. 
- Accumulated areal rainfall during the event (mm)

b) Water balance:

- Runoff threshold $\left(\mathrm{P}_{\mathrm{o}}\right)(\mathrm{mm})$ : amount of precipitation needed to generate runoff, empirically estimated for each event, from Curve Number method (SCS, 1972), adapted to Spain by Témez (1978).

- Runoff coefficient (\%): discharge as a percentage of total precipitation.

- Runoff deficit $\left(\mathrm{mm}\right.$ or $\left.\mathrm{hm}^{3}\right)$ : The difference between precipitation and flow discharge.

c) Discharge:

- Flood volume $\left(\mathrm{mm}\right.$ or $\left.\mathrm{hm}^{3}\right)$

- Peak flow $\left(\mathrm{m}^{3} / \mathrm{s}\right)$ and specific peak flow $\left(1 / \mathrm{s} / \mathrm{km}^{2}\right)$

Regarding the study of rainfall episode trend at the broader scale of River Júcar Water Authority, results obtained by Camarasa-Belmonte et al. (2020) have been used. According to this paper, 698 rainfall episodes were selected (1989-2016), following the criteria proposed by Camarasa and LópezGarcía (2006). The authors developed a method, based on thresholds of daily accumulated rainfall and intensity, to detect hydrologically significant episodes, that is, those episodes able to generate runoff, at least in a part of the basin. Selected episodes were characterised by indicators of accumulated precipitation, maximum intensity, reduced averaged intensity and persistence. These indicators were defined in the following way:

i. Accumulated precipitation: spatial mean accumulated rainfall in the episode.

ii. Maximum instantaneous intensity: absolute maximum 5-min intensity, registered in any of the gauges.

iii. Reduced average intensity: spatial averaged intensity (considering only the intervals with rainfall in each rain-gauge).

iv. Persistence: spatial mean of the persistence, that is, the probability of rain occurring during two consecutive 5-min intervals.

Taking into account these characteristics, rainfall episodes were classified by a cluster analysis into three types. Trends in frequency, accumulated rainfall and intensity were estimated for all of events and for each type of episode (Camarasa-Belmonte et al., 2020). From a geomorphic point of view, efficiency of episodes was estimated by dividing the water contribution with the number of episodes. Distinction between inland and coast episode trend were also traced.

\section{Results and discussion}

\subsection{Floods in ephemeral-streams: key issues}

Mediterranean environments, located between humid and arid climates, show an intermediate semi-arid hydrological behaviour dominated by extreme events (Brakenridge, 1988, Bracken and Crocke, 2007). Hydrological processes and flood generation in ephemeral-streams are conditioned by two key issues: the intermittence of flow and the magnitude of rainfall episode. On the one hand, most of the year the channels remain dry because they are hydrologically disconnected from the aquifer. On the other, as the discharge depends almost exclusively on the rainfall, floods are determined by the episode characteristics. 


\subsubsection{Hydrological connectivity and intermittence of flow}

Ephemeral streams show two factors of discontinuity: (1) the basin geomorphological configuration, which favours surface flow transfers to groundwater and, (2) the storm spatio-temporal variability. Bracken and Croke (2007) described static connectivity, referring to spatial patterns (physical features of catchment) and dynamic connectivity, referring to long-term landscape evolution, as well as variations in inputs of rainfall. Therefore, the intermittence of water flow can be addressed from both spatial and temporal points of view.

From a spatial perspective, hydrological connectivity, at a detailed scale, depends on the connection between patches with different hydrological soil behaviour (Yair and Kossovsky, 2002; Bracken and Croke, 2007; Wainwright et al., 2011; Bracken et al., 2013). Thus, local heterogeneity of the territory can cause discontinuity in runoff (Cammerat, 2004; Canton et al., 2011).

Additionally, at basin scale, hydrological connectivity can be interrupted because runoff becomes re-infiltrated in certain sectors of the basin. The geomorphological configuration of ephemeral streams is used to show three main sectors (Camarasa-Belmonte, 2016): (i) the steep headwaters sector; (ii) an intermediate sector, which connects headwaters to alluvial plain, where slope suddenly decreases and transitional sedimentary forms (alluvial fans, glacis, piedmonts) are developed, and (iii) the floodplain. Hydrologically, headwaters produce runoff quickly, but flow can be reabsorbed (run-on) at intermediate sectors by the permeable sedimentary forms. Streambank morphology and coarse texture of dry channels also decrease direct flow because they favour transmission losses to groundwater (Bull, 1997; Beven, 2002; Bull and Kirdby, 2002; Costa et al., 2013; Segura-Beltran and Sanchis-Ibor, 2013; Zoccatelli et al., 2019).

From a time perspective, direct runoff depends almost entirely on rainfall events. As a consequence, these systems remain dry most of the year. However, the mere occurrence of a rain episode does not guarantee the connectivity of the basin. Only events of certain magnitude ensure the flow reaches the outlet. The influence of antecedent soil moisture is relevant to the catchment connectivity (Yair and Kossovsky, 2002; Borga et al., 2014; Zoccatelli et al., 2019). Thus, both soil water reserve (on a monthly scale) and catchment moisture on an event scale (considering rain from the 5 days before the episode) should be taken into account.

Figure 2 illustrates these questions related to intermittency of flow by comparing two multipeak floods which were registered at Vernissa catchment in October 2018 (16-20) and December 2004 (3-16). Both hydrographs exhibit the strong dependence on the rainfall structure. The main difference between them derives from the intermittency of flow in October 2018 compared to the continuity of flow in December 2004. The reason for this is the total accumulated precipitation during the episode (since the intensity is similar) and water resources stored in the system since the summer. In both cases the antecedent moisture condition was dry (AMC 1).

In the October 2018 event $82 \mathrm{~mm}$ of accumulated rainfall was recorded, while in December 2004 precipitation reached $376 \mathrm{~mm}$ (Table 2). Furthermore, in December 2004 the basin had received $96 \mathrm{~mm}$ from the summer, whereas in October 2018 this was only $79 \mathrm{~mm}$. Therefore, the water stored in the catchment was greater in December 2004 than in October 2018. Thus, during a December 2004 event a base-flow of $10 \mathrm{~m}^{3} / \mathrm{s}$ was generated. Although in both events peaks of the hydrograph reproduce the rainfall structure, the accumulated and persistent precipitation of December 2004 makes the hydrological connectivity possible, similar to those of perennial fluvial systems. 


\section{December, 3-16 (2004)}

Time

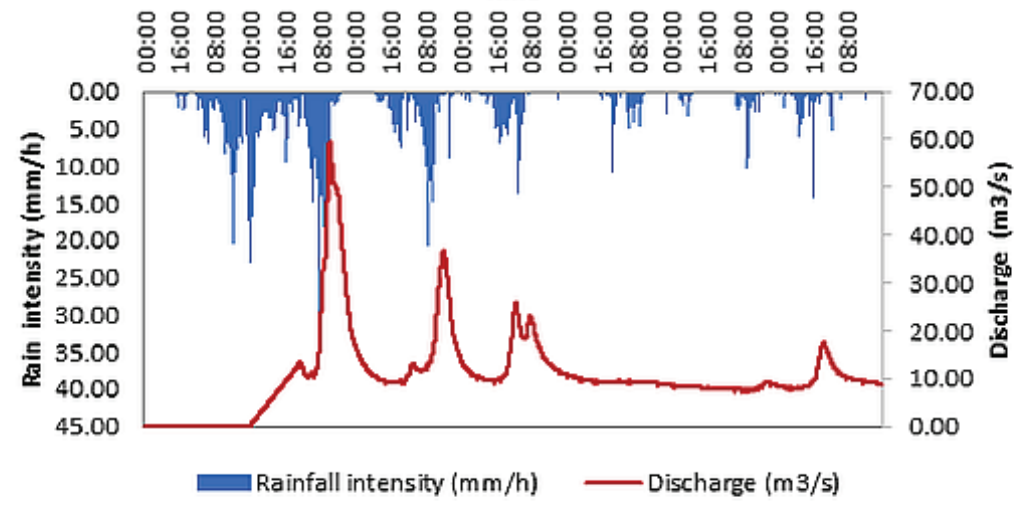

October, 16-20 (2018)

Time

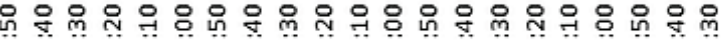

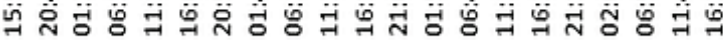

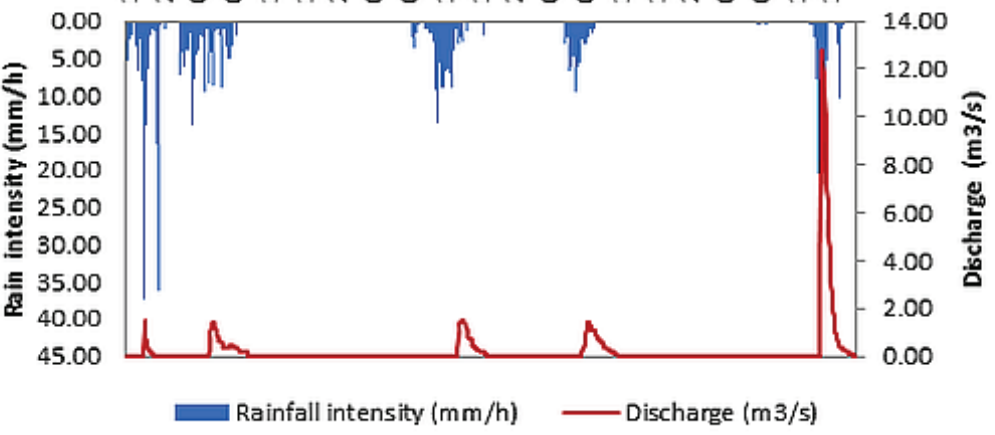

Figure 2. Comparison between two multi-peak floods registered at Vernissa catchment.

Table 2. General hydrological characteristics of multipeak floods registered at Vernissa basin (December 2004 and October 2018).

\begin{tabular}{|l|c|c|c|c|c|c|c|c|}
\hline Event & $\begin{array}{c}\text { Accum. } \\
\text { rain } \\
(\mathrm{mm})\end{array}$ & $\begin{array}{c}\text { Absolu. } \\
\text { max. } \\
\text { intensity } \\
(\mathrm{mm} / \mathrm{h})\end{array}$ & $\begin{array}{c}\text { Averag. } \\
\text { max. } \\
\text { intensity } \\
(\mathrm{mm} / \mathrm{h})\end{array}$ & $\begin{array}{c}\text { Flood } \\
\text { volume } \\
\left(\mathrm{hm}^{3}\right)\end{array}$ & $\begin{array}{c}\text { Runoff } \\
\text { coeff. } \\
(\%)\end{array}$ & $\begin{array}{c}\text { Runoff } \\
\text { deficit } \\
\left(\mathrm{hm}^{3}\right)\end{array}$ & $\begin{array}{c}\text { Runoff } \\
\text { threshold } \\
(\mathrm{mm})\end{array}$ & $\begin{array}{c}\text { Maximum } \\
\text { peak-flow } \\
\left(\mathrm{m}^{3} / \mathrm{s}\right)\end{array}$ \\
\hline December 2004 & 376 & 57 & 33 & 8.87 & 22 & 31 & 72 & 60 \\
\hline October 2018 & 82 & 139 & 37 & 0.08 & 1 & 8 & 10 & 13 \\
\hline
\end{tabular}

\subsubsection{Magnitude of episodes: the importance of single events}

One of the most important nonlinearity factors for hydrological connectivity is linked to storms: magnitude, spatial location (Zoccatelli et al., 2011) and temporal evolution (Camarasa-Belmonte, 2016).

As mentioned, flood events are due to single rainfall episodes which are large enough to generate direct quick-flow. Thus, approaching flood analysis from monthly or annual averaged rainfall data makes no sense in the Mediterranean environment, since it is dominated by extreme events (Graff, 1988; Camarasa-Belmonte and Soriano, 2014; Borga et al., 2008). On the contrary, in these basins the study should be focussed on single specific episodes of a certain magnitude, registered at a detailed scale (Zoccatelli, 2011; Zoccatelli et al., 2019). 
Yair and Raz-Yassif (2004) carried out a study in the Negev Desert (Israel) concerning runoff generation at different scales and concluded that only high episodes guaranteed the hydrological connectivity at basin scale. The importance of high magnitude events has been corroborated by, among others, Bull et al. (1999), López-Bermúdez et al. (2002) and Cammeraat (2004), when looking at catchments in southeast Spain.

The question is how to define what high magnitude episode means for a Mediterranean environment and which rainfall indicators should be used. Camarasa-Belmonte (2016) revealed how episodes, which are considered of high magnitude in relation to both indicators, accumulated rainfall and intensity, could generate runoff, floods and inundations. According to this author, accumulated rainfall influenced water balance, hydrograph volume and peak-flow, while intensity conditioned the speed of processes and the time of basin response.

\subsubsection{Large episodes regarding accumulated rainfall: the influence on water balance and discharge peaks}

Accumulated rainfall is a crucial indicator of an episode's magnitude in semi-arid environments (Yair and Raz-Yassif, 2004; Bracken et al., 2008). Zoccatelli et al. (2019) analysed rainfall-runoff processes at catchment scale in 13 ephemeral streams located in the eastern Mediterranean region. They concluded that rainfall depth and antecedent conditions were the most important properties to flood response. Similar results were obtained in south-east Spain (Bull et al., 1999; Conesa, 2005; Bracken et al., 2008).

Regarding Valencian ephemeral streams, Camarasa-Belmonte (2016) confirmed the influence of accumulated rainfall on water balance parameters (runoff threshold, runoff coefficient and runoff deficit), with runoff deficit being the most strongly correlated indicator. Thus, basin storage processes are favoured by large magnitude episodes. The flood volume and the peak flow are also significantly conditioned by accumulated rainfall. Figure 3 and Table 3 show these dependence relationships.
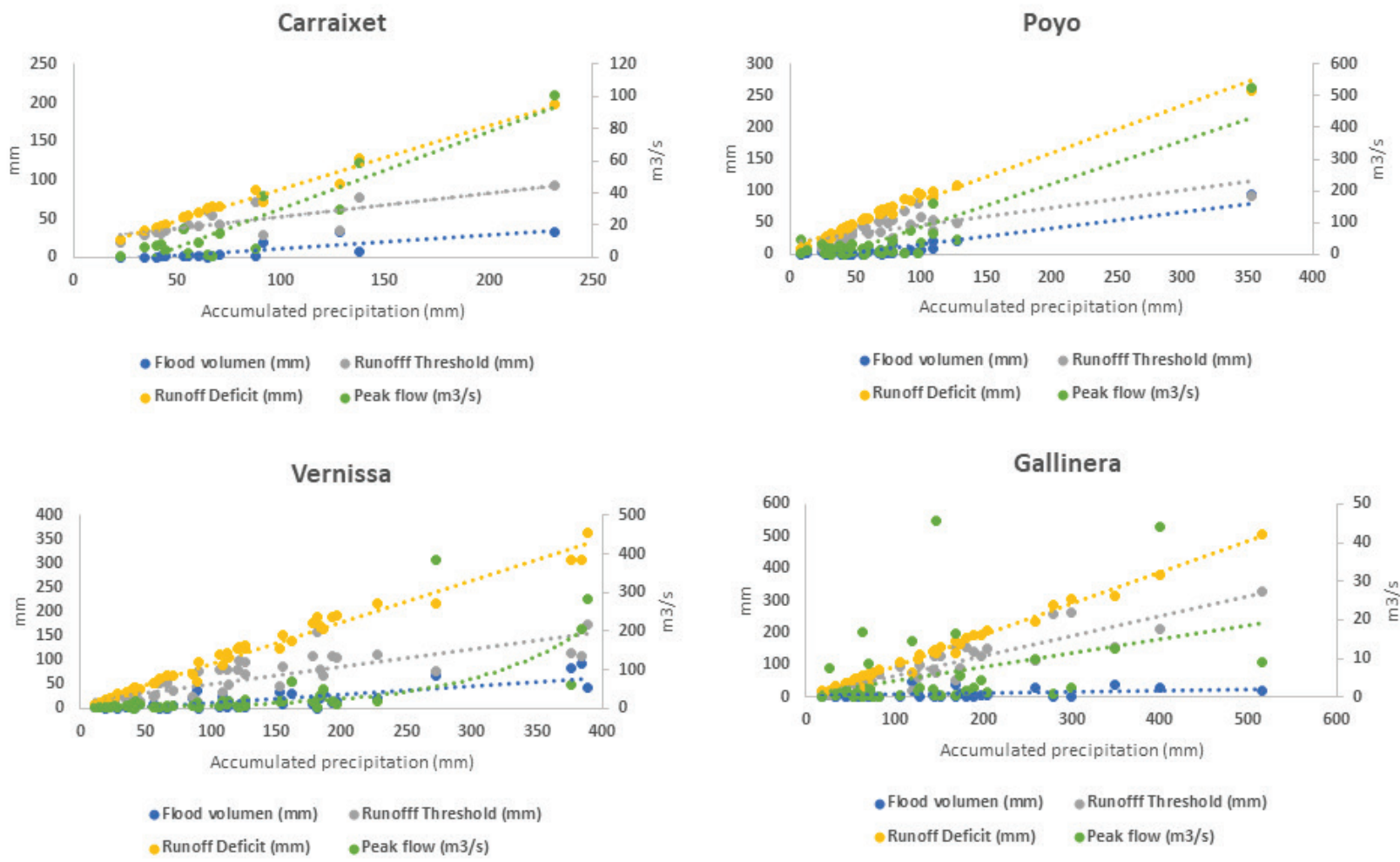

Figure 3. Influence of accumulated rainfall on water balance parameters and peak flow. 
Table 3. Correlation $\left(r^{2}\right)$ between accumulated precipitation and flood indicators.

\begin{tabular}{|l|c|c|c|c|}
\hline \multirow{2}{*}{ BASIN } & \multicolumn{2}{|c|}{ Water Balance Indicators } & \multicolumn{2}{c|}{ Discharge indicators } \\
\cline { 2 - 5 } & Runoff thresholds & Runoff Deficit & Flood volume & Peak flow \\
\hline Carraixet & 0.61 & 0.98 & 0.69 & 0.86 \\
\hline Poyo & 0.57 & 0.97 & 0.83 & 0.78 \\
\hline Vernissa & 0.67 & 0.97 & 0.65 & 0.61 \\
\hline Gallinera & 0.81 & 0.98 & 0.12 & 0.14 \\
\hline
\end{tabular}

Despite all basins having the same trend, the relationships were particular for each catchment, according to their physical characteristics. For example, in Gallinera, the influence of rainfall on discharge indicators was very low because the dataset was registered in headwaters. The gauged subbasin is small and permeable showing considerable run-on processes at the slope base.

Figure 2 also shows this behaviour in Vernissa basin, comparing floods of October 2018 and December 2004. Although the systems remained drier in October 2018 than in December 2004, runoff threshold in October is $10 \mathrm{~mm}$ while in December it is $72 \mathrm{~mm}$. Also, runoff deficit is higher in December $\left(31 \mathrm{hm}^{3}\right)$ than in October $\left(8 \mathrm{hm}^{3}\right)$ because of the accumulated rainfall.

Generally, only $6 \%$ of rainfall is converted to runoff (from runoff thresholds around $62 \mathrm{~mm}$ ), in Valencian ephemeral streams (Camarasa-Belmonte, 2016). However, in large episodes values multiply, especially concerning small and permeable catchments (Table 4). The event of October 2000 is an example for all the basins. Gallinera is very representative because during the event it showed a runoff threshold of $327 \mathrm{~mm}$, whose value when averaged is $92 \mathrm{~mm}$.

Table 4. Comparison between averaged and extreme values (October 2000 event) of accumulated rainfall and water balance indicators.

\begin{tabular}{|l|c|c|c|c|c|c|c|c|}
\hline \multirow{2}{*}{ Basin } & \multicolumn{2}{|c|}{$\begin{array}{c}\text { Accumulated } \\
\text { precipitation }(\mathrm{mm})\end{array}$} & \multicolumn{2}{c|}{$\begin{array}{c}\text { Runoff threshold. } \\
\mathrm{P}_{0}(\mathrm{~mm})\end{array}$} & \multicolumn{2}{c|}{$\begin{array}{c}\text { Runoff deficit } \\
(\mathrm{mm})\end{array}$} & \multicolumn{2}{c|}{$\begin{array}{c}\text { Runoff Coefficient } \\
(\%)\end{array}$} \\
\cline { 2 - 10 } & Averaged & $\begin{array}{c}\text { October } \\
2000 \text { event }\end{array}$ & Averaged & $\begin{array}{c}\text { October } \\
2000 \text { event }\end{array}$ & Averaged & $\begin{array}{c}\text { October } \\
2000 \text { event }\end{array}$ & Averaged & $\begin{array}{c}\text { October } \\
2000 \text { event }\end{array}$ \\
\hline Carraixet & 76.81 & 231.73 & 45.41 & 92.8 & 70.13 & 198.64 & 5.25 & 25 \\
\hline Poyo & 62.96 & 353.42 & 35.74 & 91.92 & 50.08 & 258.81 & 6.47 & 27 \\
\hline Gallinera & 142 & 514.79 & 92.8 & 327.05 & 135.26 & 505.7 & 7.74 & 56 \\
\hline Vernissa & 116.95 & 389.34 & 57.68 & 174.41 & 107.79 & 363.8 & 10.71 & 42 \\
\hline Average & 99.53 & 344.87 & 62.7 & 172.5 & 93.61 & 311.56 & 6.31 & 31 \\
\hline
\end{tabular}

In summary, high magnitude episodes (in terms of accumulated rainfall) show ambivalence towards resource and risk. On the one hand, they are the main water resource for semi-arid environments because they provide slope runoff and channel flow in addition to transferring water to the aquifer and other basin storage forms. They ensure the hydrological connectivity by making the behaviour of humid and Mediterranean fluvial systems act in a more similar way. On the other hand, they produce large discharges and peak-flows, generating important flood.

\subsubsection{Intense episodes: influence on basin response times}

Along with the accumulated rain, the intensity constitutes the other crucial indicator of episode magnitude. According to Camarasa-Belmonte and Soriano (2014), torrential rainfall and flood events are characterized more by "how it rains" than "how much it rains", because high intensities can control 
rainfall-runoff conversion processes by reducing significantly the initial infiltration soil capacity and generating runoff, even in unsaturated soils.

As the environment becomes more arid, intensity is more important than accumulated rainfall to generate runoff. Tarolli et al. (2012) found no correlation at all between runoff coefficient and rain depth for extreme events, suggesting that rain intensity had a stronger influence than accumulated rain on runoff generation. Zoccatelli et al. (2019) verified this idea and highlighted the role of the aridity, by contrasting flood generation in desert and Mediterranean catchments.

Camarasa-Belmonte (2016) found a significant correlation between rain intensity indicators and the basin response times, especially lag time. As maximum intensity increased, lag time decreased (Fig. 4). Duration of lag time showed a clear seasonal behaviour, being shorter in summer and early autumn, when rainfall episodes were more intense.

However, besides the magnitude of rainfall intensity, the flood generation is conditioned by the moment, at the beginning or the end of the storm, by which time the maximum intensity is reached (Dunkerley, 2012). The influence of rainfall structure on the hydrograph shape can be observed in Figure 5 , by comparing accumulation curves of rainfall and discharge in two events registered in Carraixet basin (September 1990 and December 2007) (Camarasa-Belmonte, 2016).

In the event of September 1990, maximum intensity $(80 \mathrm{~mm} / \mathrm{h})$ occurred at the beginning. The catchment barely had time to react and hydrograph reproduced the shape of hyetograh (lag time $1.6 \mathrm{~h}$ ). In December 2007 maximum intensity was lower $(11.5 \mathrm{~mm} / \mathrm{h})$ and took place at the end of the storm. Rainfall-runoff processes were influenced by the operation of the basin and, in consequence, the accumulated curves of rain and flow differed greatly. Lag time was longer $(11.5 \mathrm{~h})$.
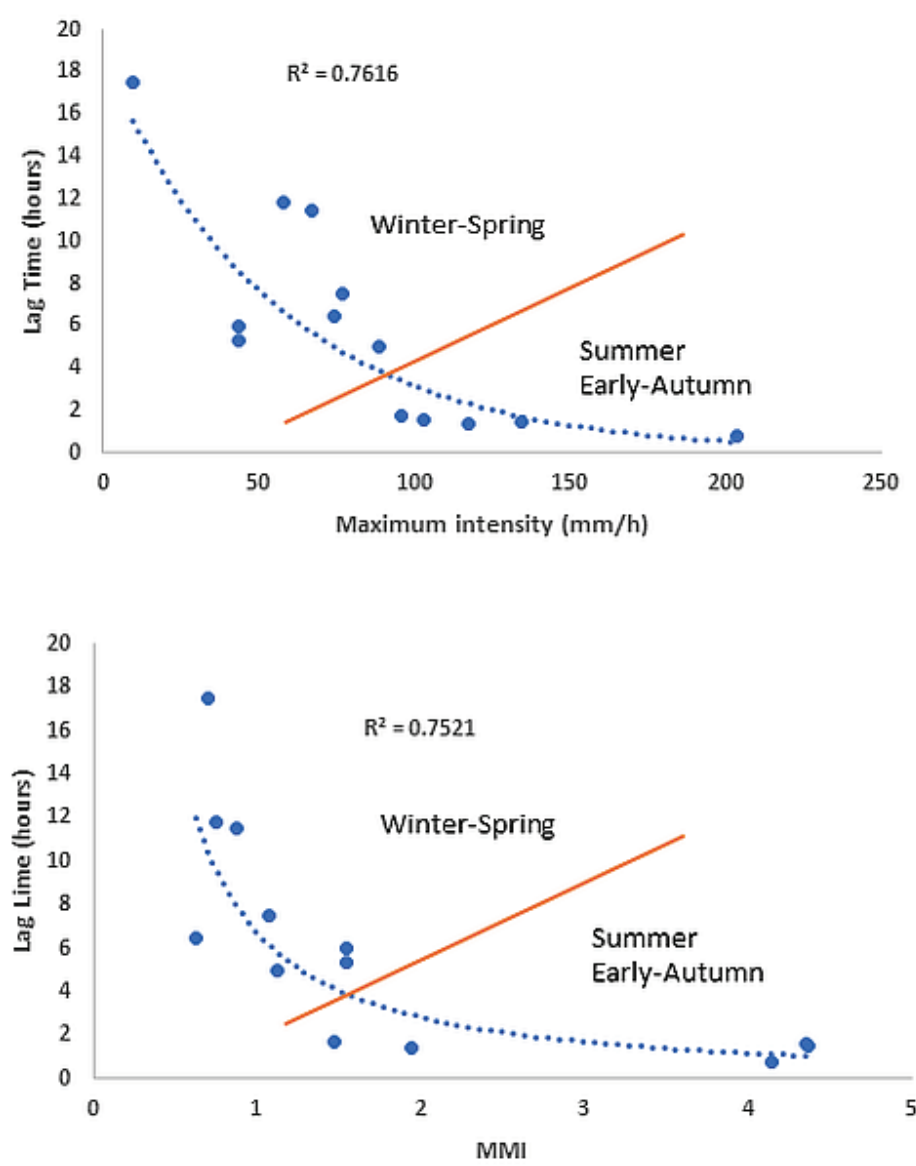

Figure 4. Influence of maximum intensity and MMI on lag time. 


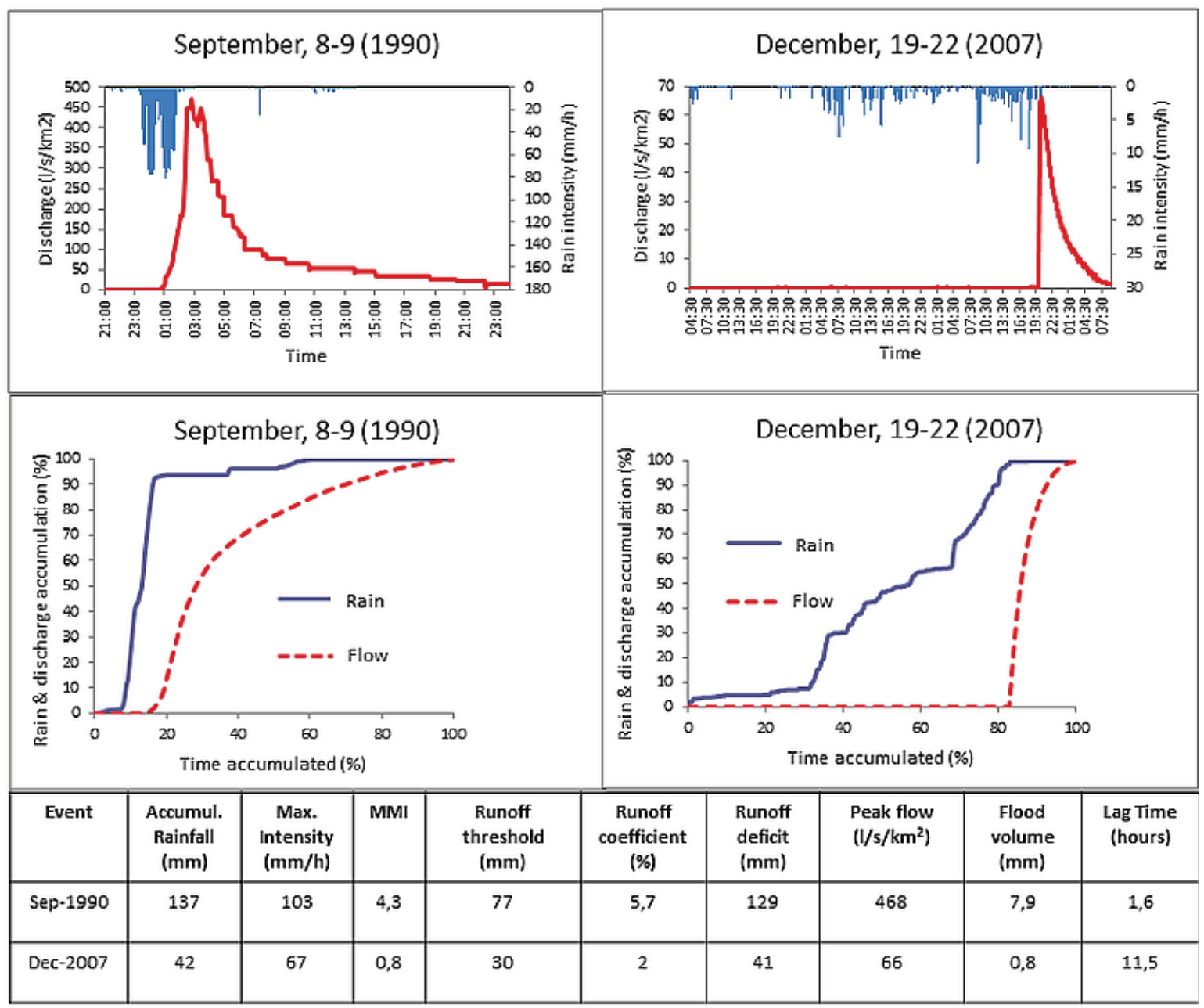

Figure 5. Comparison between hydrographs and accumulation curves of rainfall and discharge (Carraixet, September 1990 and December 2007).

In order to analyse the influence of the intensity structure on the hydrograph, CamarasaBelmonte (1016) developed the Momentum of Maximum Intensity Index (MMI). The MMI was applied to different flash floods registered at Carraixet basin under dry antecedent moisture condition (AMC I), and concluded that two types of event could be distinguished:

(i) Events where higher intensities occurred, concentrated at the beginning of the episode (high values of MMI). Hydrographs reproduced the shape of the hyetographs (showing very similar rain and discharge accumulation curves), because the catchment did not have time to intervene in rainfall-runoff conversion processes. Runoff thresholds were low and the response times of the catchment were very short (lag time of around $1 \mathrm{~h}$ ). In these cases, the hydrological connectivity was due to high intensity and peak flow which used to be high and fast (time to peak, around 1h). These types of episode generate the most dangerous flash-floods, from the point of view of risk, because a high flow peak can be quickly reached, leaving the population with no time to react.

(ii) Events where higher intensities occurred at the end of the episode (low values of MMI). In these cases, hyetographs and hydrographs did not show the same structure, because the catchment influenced the outputs (infiltration and other rainfall-runoff conversion processes modified the inputs's shape). Runoff thresholds were greater (as well as peak flow) and hydrological connectivity was due to accumulated precipitation. The response times of the basin were longer, so the population had more time to react and risk could 
be prevented. Even though the hydrograph showed a sharp peak, these types of episode could be interpreted as resource because they provided water to the fluvial system (filling either, surface and subsurface storages).

In summary, when maximum intensities occurred at the beginning of the episode, lag times were reduced and the structure of inputs (rain) and outputs (discharge) were very similar. Flash-flood was quickly generated and transferred along the channel network, creating a very risky situation for the population. However, when intensities occurred at the end of the episode, the model changed. The basin influence was higher, as well as water storage, that is runoff thresholds increased and runoff coefficients decreased. Lag time was longer and so was the time to react to risk. Thus, in this type of episodes resources increased and risk decreased. Camarasa-Belmonte (2016) also observed certain seasonality of events. The most dangerous flash-floods tended to be generated in summer and early autumn (caused by powerful convective cells), while those associated with the resource tended to be produced in spring and winter (associated with frontal rains).

Concerning the October 2018 event registered in Vernissa (Fig. 2), the first, second and final flow-peaks will be analysed. The first one $\left(59 \mathrm{~m}^{3} / \mathrm{s}\right)$ was caused by the highest intensity $(33.4 \mathrm{~mm} / \mathrm{h})$ which occurred at the beginning of the storm. The catchment reacted quickly (lag time $5 \mathrm{~h} 30^{\prime}$ ). The second peak was lower $\left(36.7 \mathrm{~m}^{3} / \mathrm{s}\right)$ due to reduced intensity $(20.17 \mathrm{~mm} / \mathrm{h})$. Thus, even though there was base flow with a consequent decrease in the channel friction, the lag time increased $(7 \mathrm{~h})$. The final peak $\left(17.49 \mathrm{~m}^{3} / \mathrm{s}\right)$ was produced by low rainfall intensity $(14.34 \mathrm{~mm} / \mathrm{h})$, but after several floods the channel travel time was reduced (lag time $5 \mathrm{~h} 20^{\prime}$ ).

\subsection{Flash flood evolution under environmental change conditions}

Once the specificity of ephemeral stream hydrology has been highlighted, an analysis of future trends of these systems under current environmental change condition proceeds. Climate change is destabilizing natural systems. However, the anthropic pressure, far from alleviating the situation, contributes to disturbing the morphogenetic balance of ephemeral streams. Obviously, this synergy implies a significant increase in flash-flood risk in systems which, due to the intermittence of flow, are not perceived as areas at risk, thereby increasing their vulnerability.

\subsubsection{Climate change: rainfall event trends}

Nowadays, it is unquestionable that the climate is changing. According to the Fifth Assessment Report of the Intergovernmental Panel on Climate Change, an increase in the average temperature of the planet is expected until 2100 , between $0.3^{\circ}$ and $1.7^{\circ}$ for the best-case scenarios and, between 2.6 and $4.8^{\circ}$ for the worst-case scenarios. The effects on precipitation and flow are not clear, because of the considerable variability of rainfall, especially in transition environments such as Mediterranean areas. However, there is consensus about the increase intense events in the world (Xoplaki et al., 2012; Romera et al., 2017). Under a general climate change, arid and semi-arid zones will suffer the worst impact due to its precarious water balance.

In Spain, even though general tendencies cannot be entirely confirmed, the studies point to a decrease in average precipitation during winter, spring and summer, and an increase in intensity in Alicante and Murcia (Valdés-Abellan et al., 2017). According to most indicators the Mediterranean side will experience the greatest impact because of a marked decrease in Atlantic rains, which mainly affect inland areas, between the spring and summer transition (Miró et al., 2015; Marcos-García and PulidoVelazquez, 2017). González-Herrero and Bech (2017), in their study on rainfall episodes in Spain (18052014), found that the frequency of heavy rains increased (especially on the Mediterranean coast), while 
accumulated precipitation remained stable. Olcina (2017) also verified an increase in flood events due to heavy rains in Alicante between 1977 and 2016.

Camarasa-Belmonte et al. (2020) carried out a study on rainfall evolution between 1989 and 2016 in the territory of Jucar Water Authority where 698 episodes were selected and characterised according to their indicators of accumulated rainfall, intensity and persistence. Using an objective cluster analysis, episodes were classified into three types:

1. Episodes of high frequency and low magnitude; interpreted as limited resource free of risk.

2. Episodes of low frequency and high magnitude, that bring abundant water resources to the system, but which can also involve risk; described as high resource not risk free.

3. Episodes of intermediate frequency and heavy intensity clearly interpreted as high risk and low resource.

The analysis of event tendency showed an increase in intensity and a decrease in accumulated precipitation for the three types of episode (which means greater risk and less resource). Figure 6 shows this trend for episodes type 2 (high resource not risk free). Heavy rainfall involves associated risks concerning daily life disruptions (traffic congestion, overflow of urban pipes, etc.) provoked by intense rainfall in situ. In other words, Mediterranean events are becoming increasingly dangerous.

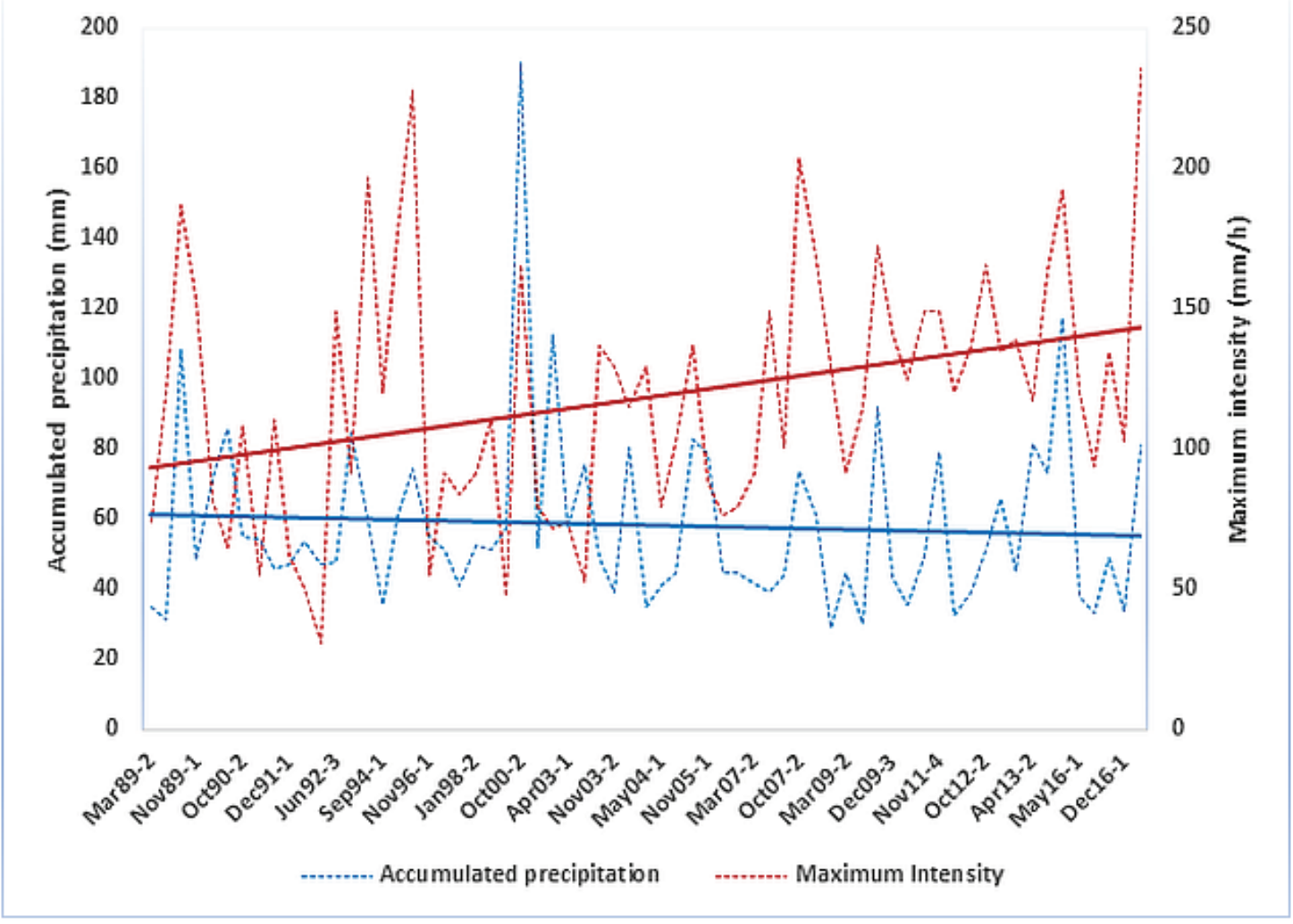

Figure 6. Trend of accumulated precipitation and maximum intensity in episodes type 2 (high resource not risk free), between 1989-2016, in the Jucar River Water Authority. 
Consequences of climate change to Mediterranean ephemeral streams are very uncertain and controversial (Zoccatelli et al., 2019). Yair and Kossovsky (2002) suggest "the possibility that the same regional climatic change might have different, or even opposite, effects on the hydrological regime". According to these authors, in semi-arid areas the shift to drier and warmer conditions could increase connectivity because the expected loss of vegetation would reduce infiltration and increase both runoff and soil erosion. Conversely, in arid areas connectivity would decrease, being limited to very extreme events. Yair and Raz-Yassif (2004) highlight the role of the scale. Thus, at headwaters runoff could increase due to the very low rain threshold required to produce flow in rocky areas (supposing erosion had removed soil and sediments). However, at a basin scale, water losses could increase because of channel transmission and other sedimentary forms, so connectivity would depend on antecedent moisture and rainfall intensity.

In summary, expected changes in ephemeral streams, derived from the increase in rainfall intensity and decrease of accumulated rainfall, apparently point to the idea of an increase of risk. At basin scale, connectivity will be determined by the intensity rather than by the accumulated rain, thereby making the flow response and the generation of flash-flood more impulsive. Consequently, lag time will be reduced, as well as the reaction time of the population to floods, which increases the risk. At the same time, water resources would be reduced due to fast drainage of surface flow. The "lack of time" for water to infiltrate will hinder water storage in natural reservoirs of basin (channel, piedmonts, sediments, flood-plain...).

\subsubsection{Anthropic change: degrading natural systems and accelerating the water cycle}

Despite the intermittency of surface resources, the Mediterranean environments have supported a strong agricultural use for more than 8,000 years. Historically, sustainable exploitation was achieved through soil conservation, water use and control of flood and erosion risks. According to Butzer (2005), the Mediterranean environment, often described as highly degraded, has been able to develop strong ecological and human resilience against degradation. However, recent changes in land use are dangerously compromising these precarious balance resources/risks (Barredo and Engelen, 2010; Durán et al., 2014).

Changes mainly affect two basic aspects: (1) the rain-runoff conversion processes and (2) the way ephemeral-streams operate as drainage systems. The anthropic action causes alterations in the runoff generation (essentially through changes in land use) and in drainage through engineering interventions on river beds and areas of flooding.

\subsubsection{Runoff generation and soil losses}

Camarasa-Belmonte et al. (2018) analysed the effects of land use changes (1956-2011) on runoff generation and soil loss at Carraixet basin (Fig. 7). Only 26\% of basin area maintained the same use, while $74 \%$ showed different changes, mainly a decrease in dry land (32\%) due to the citrus increase $(15 \%)$ and a lost in forest mass $(23 \%)$ in favour of scrub and artificial cover $(13 \%)$. 


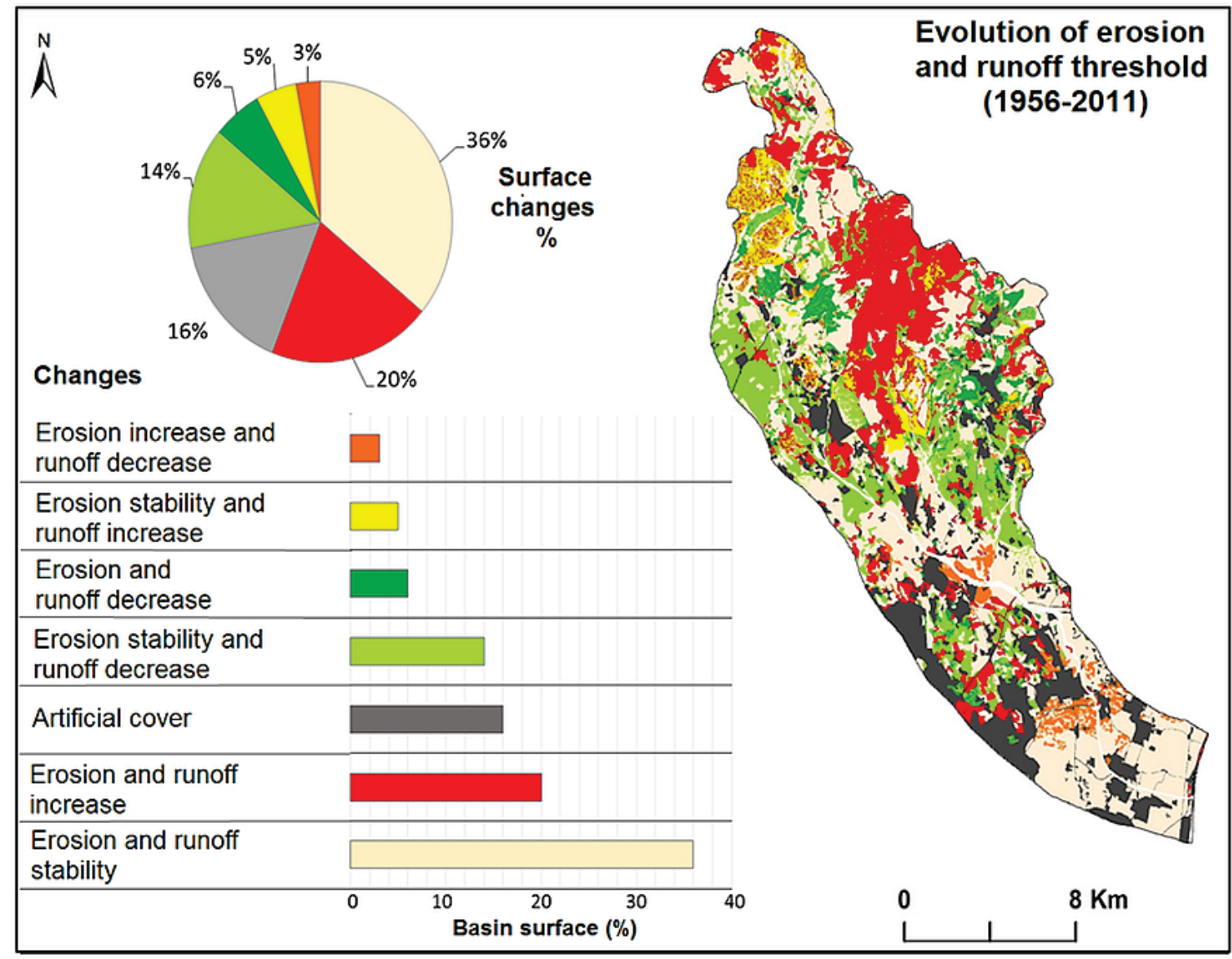

Figure 7. Combined evolution of erosion and runoff balances in Carraixet basin between 1956 and 2011 (Source, Camarasa et al., 2018, modified).

The natural system reacted by adapting the erosive dynamics and runoff generation processes to new uses. According to this study, runoff production processes reacted faster and more intensively than soil loss. Thus, while erosive changes affected $33 \%$ of basin surface, changes in runoff production, which were much more dynamic, affected $62 \%$. The whole area has been affected by both the runoff process and the soil loss process, with only $36 \%$ of the basin remaining stable. $64 \%$ of the area simultaneously presented alterations to both the erosion and runoff processes, showing negative synergies towards degradation (20\%) and positive synergies towards improvement $(6 \%)$.

In summary, anthropic land use modifications are significantly altering the resource-risk balance, increasing the erosion and flood risk, and decreasing water and soil resources.

\subsubsection{Decreasing water basin storage and accelerating drainage}

As mentioned before, the rainfall intensity increase can unbalance rainfall-runoff processes, generating runoff in soils which are not saturated. Therefore, discharge concentrates rapidly, generating flash floods which are very dangerous from the point of view of risk. The water cycle accelerates because infiltration is reduced. Artificializating and sealing the soil increases the process. The water that should be stored in soils, terraces and other sedimentary forms is drained into the sea, in a few hours, without having filled the different natural reservoirs of the basin. From the point of view of resources, this means significant losses for both natural ecosystems and human activity.

Given this scenario most structural flood control measures contribute to reducing the time permanence of water in the system. Anthropic interventions in which river beds are shortened and 
straightened, especially those that meander, are very frequent. Engineering works increase drainage speed by rectifying and widening the channels, decreasing friction and increasing their slopes. Along with the evacuation speed, the erosive power of the waters accelerates. As a consequence, the channel loses the hydrological connectivity with the adjacent geomorphological units (terraces, plains, etc.) and drains the excess water into the sea quickly as there is insufficient time and space to transfer water to the aquifers.

According to Camarasa-Belmonte (2020) "high energy events must have time and space to be regulated. Anthropogenic intervention should not contribute to draining resources from the basin as soon as possible, but rather to storing them naturally, because otherwise we are contributing to an increase in risk, a decrease in the resource and a destabilization of the system". In this sense, new green-blue adaptive initiatives are becoming increasingly common, compared to the usual grey flood control infrastructures (Alves et al., 2019). The aim is to restore water balance in headwaters (runoff-producing areas) while maintaining maximum hydrological connectivity in the whole basin. In terms of river restoration, geomorphological strategies are being used which respect the so called "Territory of River Mobility" (channel, river corridor and part of the floodplain used by the river for energy readjustments) (Ollero, 2015). Thus, floods are laminated, the peak flow is reduced, part of the water is transferred to the aquifers, and the amount of resource which is discarded into the sea is delayed and reduced.

\subsubsection{Geomorphic change: morphogenetic disequilibrium process-form}

The geomorphological evolution of semi-arid fluvial systems occurs because of the morphogenetic action of extreme events (Brakenridge, 1988). According to Graff (1988) in Mediterranean environments, processes control forms in episodes of great magnitude, while forms control processes in those of low magnitude. Therefore, the magnitude of episodes is crucial for landscape changes. In this sense, according to Bull (1997), ephemeral streams are morphogenetic systems which are continuously imbalanced, since during high energy events, channels and floodplains adapt to large peak flows, while for the rest of the time, the channels begin to be filled with sediments and vegetation in order to adapt the forms to low discharge or even an absence of flow.

Wolman and Gerson (1977) introduce the concepts of effectiveness and recovery period to assess the geomorphic work done by individual events in a particular morpho-climatic environment. Thus, the effectiveness is "the ability of an event or combination of events to affect the shape or form of the landscape", while recovery period is "the time required for a landform to recover the form existing prior to the event". According to these authors, large low-frequency events make up the landscape whereas restorative processes act during episodes of high frequency and low energy, to recover original morphology. This equilibrium is closely linked to morphoclimatic environments. Thus, after extraordinary events, channels of humid environments could take between a few months and a few years to recover their shape those of semi-arid environments could require several decades, and those of arid environments could take hundreds of years, or in fact might never recover their initial form (Wolman and Gerson, 1978).

At this point the question is how environmental changes would affect the morphogenetic activity in ephemeral streams. Figure 8 illustrates trends for episodes registered at the Jucar Water Authority from 1989 to 2016. Figure 8a shows an increase in high intense episodes, while Figure 8b reveals how the efficiency of frequent low magnitude events is decreasing. Due to climate change, morphogenetic phases could intensify in the long term because of the intense episode augmentation with high erosive efficiency. At the same time, the system restoration capacity would be reduced because the efficiency of low magnitude episodes is decreasing, thereby increasing recovery times. These trends contribute to the destabilization of Mediterranean fluvial systems and again point to the increase in risk and the reduction of resources. 

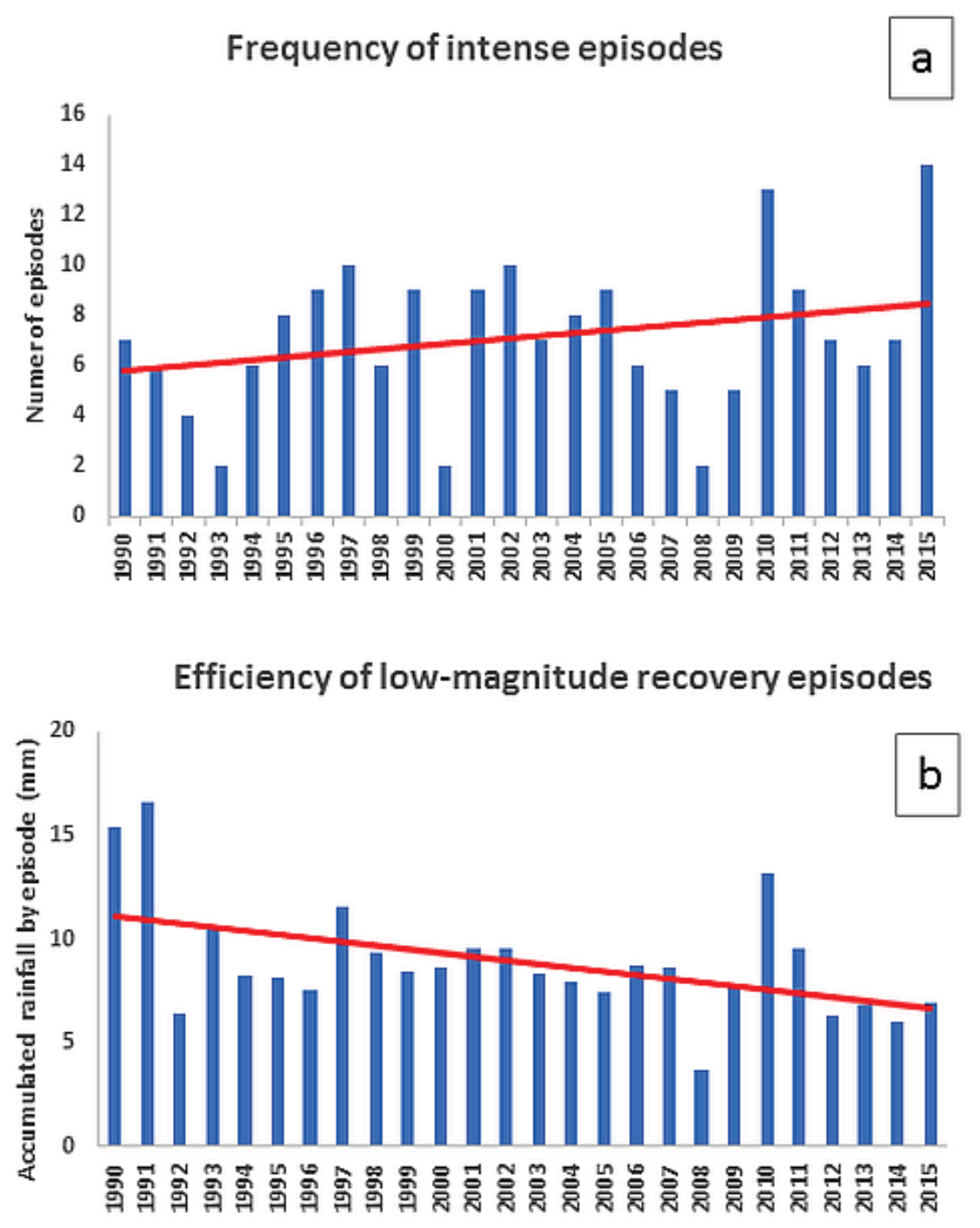

Figure 8. Evolution of episodes in the Jucar River Water Authority (1989-2016). a) Frequency of intense episodes; b) Efficiency of low magnitude recovery episodes (Source: Camarasa-Belmonte, 2020 modified).

\section{Conclusions}

Mediterranean ephemeral streams are intermittent flow river systems which involve a greater risk of flooding than initially expected. Environmental planning and land use legislation are increasingly aware of their hydro-geomorphological specificities. That is how the European Flood Directive supports the analysis of this type of basin, on a detailed scale and adapting the methodology to its characteristics. The present work, based on the compilation of previous studies carried out in eastern Spain, highlights the key issues that define Mediterranean hydrology and its foreseeable evolution in a context of environmental change.

Two basic characteristics are crucial for flood generation in ephemeral streams: the intermittency of flow and the magnitude of episodes (which makes flow continuity towards the mouth possible). Due to the catchment hydro-geomorphological configuration, channels are disconnected from the aquifers, and flow depends exclusively on the rain. However, not all episodes generate runoff. Only major events ensure sufficient connectivity between the different elements of the basin (especially sedimentary transitional forms) in order to generate flow. 
The magnitude of episodes can be described by the volume of accumulated water as well as by the intensity of rainfall. The accumulated precipitation mainly determines the volume of the hydrograph and the peak flow through its influence on the water balances (significant correlation between accumulated rainfall and the deficits and runoff thresholds have been found). Maximum intensities determine the response times of basins, evidenced by the significant negative correlation between maximum intensity and catchment lag time. Furthermore, not only are maximum intensity values important, but also the moment at which they occur, namely either at the beginning or at the end of the storm. When the highest intensities occur at the beginning of the storm, catchment lag time is reduced and a great similarity between rain and discharge can be observed. The basin hardly has time to intervene in rainfall-runoff conversion processes, thus runoff thresholds drop and runoff coefficients rise. Conversely, when maximum intensities occur at the end, the basin influence is evident, water transfers to the aquifer augment, runoff coefficient and peak flow decrease, and lag time increases. Consequently, events with high intensities at the onset of rainstorm entail a significant risk, whereas if the maximum intensities are lower and recorded at the end, they constitute a resource.

The trend in Mediterranean episodes is towards increasing intensity and decreasing accumulated rainfall. As a consequence, hydrological connectivity will become more dependent on rain intensity, thus reducing runoff thresholds (less water storage) and basin response times. Anthropic changes enhance this behaviour, by reducing infiltration and increasing surface runoff and erosion while accelerating the hydrological cycle.

Focusing on the current context of environmental change, the evolution of ephemeral streams hydrology points to a clear increase in risk to the detriment of the resource. This behaviour, which is more pronounced inland than on the coast, makes it difficult to store resources in headwaters (which are mostly located inland), and at the same time it increases risk downstream in more populated floodplains on the coast. Conversely, from an anthropic point of view, changes in land use and flood control structural measures, far from alleviating the problem, accelerate the drainage of water into the sea, making it difficult to store the resource in the basin's natural reservoirs (soils, terraces, aquifers). As a consequence, in the long term an increase of process-form disequilibrium in Mediterranean ephemeral streams can be expected, as well as a progressive aridification of these fluvial systems.

Reversing this trend implies adaptation strategies based on flexibility. We must be aware that a large part of flood control, mitigation and management measures of the $20^{\text {th }}$ century have become obsolete today because they are too narrow and rigid. We cannot forget that we are in a context of change, and natural systems need time and space to adapt. In this sense, conservationist approaches to the environment should prevail because reducing risk involves developing resilient systems compatible with natural dynamics. Therefore, increasing knowledge of ephemeral stream hydro-geomorphology is essential to developing 21 st century solutions to the problems of the current and following centuries.

\section{Acknowledgements}

The authors acknowledge the support of Project No. CGL2017-83546-C3-1-R (funded by the Spanish Ministry of Science and Innovation and co-funded by the European Regional Development Fund, ERDF). The authors would also like to thank the Júcar River Water Authority (in particular, the SAIH Service) for access to the hydrological data. Finally, the authors wish to acknowledge the reviewers and editors.

\section{References}

Alves, A., Gersonius, B., Kapelan, Z., Vojinovic, Z., Sanchez, A. 2019. Assessing the Co-Benefits of green-bluegrey infrastructure for sustainable urban flood risk management. Journal of Environmental Management 239, 244-254, https://doi.org/10.1016/j.jenvman.2019.03.036 
Barredo, J.I., Engelen, G. 2010. Land Use scenario modelling for flood risk mitigation. Sustainability 2 (5), $1327-$ 1344. https://doi.org/10.3390/su2051327

Beven, K. 2002. Runoff Generation in semi-arid areas. In: L.J. Bull, M.J. Kirkby (Eds.), Dryland Rivers: Hydrology and Geomorphology of Semi-Arid Channels. John Wiley and Sons, 57-105, Chichester, England.

Borga, M., Gaume, E., Creutin, J.D., Marchi, L., 2008. Surveying flash floods: gauging the ungauged extremes. Hydrol. Process. 22 (18), 3883-3885 https://doi.org/10.1002/hyp.7111

Borga, M., Stoffel, M., Marchi, L., Marra, F., Jakob, M. 2014. Hydrogeomorphic response to extreme rainfall in headwater systems: flash floods and debris flows. Journal of Hydrology 518, 194-205. https://doi.org/10.1016/j.jhydrol.2014.05.022

Bracken, L.J., Croke, J. 2007. The concept of hydrological connectivity and its contribution to understanding runoff-dominated geomorphic system. Hydrological Processes 21, 1749-1763. https://doi.org/10.1002/hyp.6313

Bracken, L.J., Cox, N. J., Shannon, J. 2008. The relationship between rainfall inputs and flood generation in southeast Spain. Hydrological Processes 22, 683-696. https://doi.org/10.1002/hyp.6641

Bracken, L.J., Wainwright, J., Ali, G. A., Tetzlaff, D., Smith, M.W., Reaney, S.M., Rou, A.G. 2013. Concepts of hydrological connectivity: Research approaches, pathways and future agendas. Earth-Science Reviews 119, 17-34. https://doi.org/10.1016/j.earscirev.2013.02.001

Brakenridge, G.R. 1988. River flood regimen and floodplain stratigraphy. Floods Geomorphology. John Wiley \& Sons, pp. 139-155. New York.

Bull, W.B., 1997. Discontinuous ephemeral streams. Geomorphology 19, 227-276. https://doi.org/10.1016/S0169$555 \mathrm{X}(97) 00016-0$

Bull, L.J., Kirkby, M.J. 2002. Dryland river characteristics and concepts. In: L.J. Bull, M.J. Kirkby (Eds.). Dryland Rivers: Hydrology and Geomorphology of Semi-Arid Channels. John Wiley \& Sons: Chichester, England.

Bull, L.J., Kirkby, M. J., Shannon, J., Hooke, J.M. 1999. The impact of rainstorms on floods in ephemeral channel in southeast Spain. Catena 38, 191-209. https://doi.org/10.1016/S0341-8162(99)00071-5

Butzer, K.W. 2005. Environmental history in the Mediterranean world: cross-disciplinary investigation of causeand-effect for degradation and soil erosion. Journal of Archaeological Science 32, 1773-1800. https://doi.org/10.1016/j.jas.2005.06.001

Calsamiglia, A., García-Comendador, J., Fortesa, J., López-Tarazón, J.A., Crema, S., Cavalli, M., Calvo-Cases, A., Strany, J. 2018. Effects of agricultural drainage systems on sediment connectivity in a small Mediterranean lowland catchment. Geomorphology 318, 162-171. https://doi.org/10.1016/j.geomorph.2018.06.011.

Camarasa-Belmonte, A.M. 2016. Flash floods in Mediterranean ephemeral streams in Valencia Region (Spain). Journal of Hydrology 541(Part A), 99-115. https://doi.org/10.1016/j.jhydrol.2016.03.019

Camarasa-Belmonte, A.M. 2020. Cambio global y sostenibilidad. En: J. Farinós (Coor.) Desafios y oportunidades de un mundo en transición. Una interpretación desde la Geografía, PUV, 29-40.

Camarasa-Belmonte, A.M., López-García, M.J. 2006. Criterios de selección y caracterización de episodios de lluvia. Aplicación a la Confederación Hidrográfica del Júcar (1989-2003). Clima, Sociedad y Medio Ambiente, Publicaciones AEC, Serie A, 5, 323-336.

Camarasa-Belmonte, A.M., Soriano, J. 2014. Empirical study of extreme rainfall intensity in a semi-arid environment at different time scale. Journal of Arid Environments 100-101, 63-71. https://doi.org/10.1016/j.jaridenv.2013.10.008

Camarasa-Belmonte, A.M., Caballero López, M.P., Iranzo García, E., 2018. Cambios de uso del suelo, producción de escorrentía y pérdida de suelo. Sinergias y compensaciones en una rambla mediterránea (Barranc del Carraixet, 1956-2011). Boletín de la Asociación de Geógrafos Españoles 78, 127-153. https://doi.org/10.21138/bage.2714.

Camarasa-Belmonte, A.M., Rubio, M., Salas, J. 2020. Rainfall events and climate change in Mediterranean environments: an alarming shift from resource to risk in Eastern Spain, Natural Hazards 103, 423-445. https://doi.org/10.1007/s11069-020-03994-x 
Cammeraat, E. 2004. Scale dependent thresholds in hydrological and erosion response of a semi-arid catchment in southeast Spain. Agriculture, Ecosystems and Environment 104, 317-332. https://doi.org/10.1016/j.agee.2004.01.032

Cantón, Y., Solé-Benet, J., De Vente, J., Boix-Fayos, C., Calvo-Cases, A., Asensio, C., Puigdefábregas, J. 2011. A review of runoff generation and soil erosion across scales in semiarid south-eastern Spain. Journal of Arid Environments 75 (12), 1254-1261. https://doi.org/10.1016/j.jaridenv.2011.03.004

Conesa, C. 2005. Les 'ramblas' du Sud-est Espagnol: Systèmes hydromorphologiques en milieu méditerranéen. Zeitschrift für Geomorphologie 49, 205-224.

Costa, A.C., Foerster, S., Araújo, J.C., Bronstert, A. 2013. Analysis of channel transmission losses in a dryland river reach in north-eastern Brazil using streamflow series, groundwater level series and multi-temporal satellite data. Hydrological Processes 27, 1046-1060. https://doi.org/10.1002/hyp.9243

Dunkerley, D.L. 2012. Effects of rainfall intensity fluctuations on infiltration and runoff: rainfall simulation on drylands soils, Fowlers Gap, Australia. Hydrological Processes 26, 2211-2224. https://doi.org/10.1002/hyp.8317

Durán, Z.V.H., Rodríguez, P.C.R., Cuadros, T.S., Francia, M.J.R. 2014. Impacto de la erosión y escorrentía en laderas de agroecosistemas de montaña mediterránea. Ecosistemas 23(1), 66-72.

Estrela, M.J., Piró, J.J., Gómez, I. 2016. Clima y cambio climático en la Comunidad Valenciana. El Territorio Valenciano. Transformaciones ambientales y antrópicas 25-28.

European Environment Agency. 2019. River floods, climate change adaptation. Water and Marine Environments. https://www.eea.europa.eu/data-and-maps/indicators/river-floods-3/assessment. Accessed 31Jul 2020.

Feng, S., Fu, Q. 2013. Expansion of global drylands under a warming climate. Atmos. Chem. Phys. 13, 1008110094. https://doi.org/10.5194/acp-13-10081-2013

Gómez, R., Hurtado, I., Suárez, M.L., Vidal-Abarca, M.R. 2005. Ramblas in south-east Spain: threatened and valuable ecosystems. Aquat. Conserv. 15, 387-402. https://doi.org/10.1002/aqc.680

González-Herrero, S., Bech, J. 2017. Extreme point rainfall temporal scaling: a long term (1805-2014) regional and seasonal analysis in Spain. International Journal of Climatology 37(15), 5068-5079. https://doi.org/10.1002/joc.5144

Graff, W.L. 1988. Fluvial processes in dryland river, Springer, 345 pag., Berlin.

López-Bermúdez, F., Conesa-García, C., Alonso-Sarriá, F. 2002. Floods: magnitude and frequency in ephemeral streams of the Spanish Mediterranean Region. In: L. J. Bull, M. J. Kirkby (Eds.). Dryland Rivers: Hydrology and Geomorphology of Semi-Arid Channels. John Wiley and Sons, 329-350 pag., Chichester, England.

Marcos-García, P., Pulido-Velázquez, M. 2017. Cambio climático y planificación hidrológica: ¿es adecuado asumir un porcentaje único de reducción de aportaciones para la demarcación? Ingeniería del Agua 21(1), 35-52. https://doi.org/10.4995/ia.2017.6361

MINECO (Ministerio para la Transición Ecológica). 2018. Inundaciones y Cambio Climático, Madrid. https://www.miteco.gob.es/es/agua/temas/gestion-de-los-riesgos-de-inundacion/libro-cambio-climaticoinundaciones-web-06092019_tcm30-499367.pdf (accessed 31 July 2020).

Miró, J.J., Estrela, M.J., Olcina, J. 2015. Statistical Downscaling and attribution of air temperature change patterns in the Valencia Region (1948-2011). Atmospheric Research 156, 189-212. https://doi.org/10.1016/j.atmosres.2015.01.003

Morrell, J., Pérez-Cueva, A. 2000. Volúmenes hídricos de las precipitaciones intensas en la Confederación Hidrográfica del Júcar. Cuadernos de Geografia 67/68, 261-275.

Olcina, J. 2017. Incremento de episodios de inundación por lluvias de intensidad horaria en el sector central del litoral mediterráneo español: análisis de tendencias en Alicante. SÉMATA, Ciencias Socias e Humanidades 29, 143-163. http://hdl.handle.net/10045/73413

Ollero, A. 2015. Buenas Prácticas en Restauración Fluvial (10 ejemplos). Informe técnico. https://doi.org/10.13140/RG.2.2.21171.84002

Petrakis, M., Giannakopoulos, C., Lemesios, G. 2012. Report on observed changes and responses to climate change worldwide and in Cyprus. CYPADAPT- development of a national strategy for adaptation to 
climate change adverse impacts in Cyprus. LIFE10 ENV/CY/000723. DELIVERABLE 1.1. National Observatory of Athens, Athens, Greece. Available at: http://cypadapt.uest.gr/wpcontent/uploads/DELIVERABLE1.1.pdf

Romera, R., Gaertner, M.A, Sánchez, E., Domínguez, M., González-Alemán, J.J., Miglietta, M.M. 2017. Climate change projections of medicanes with a large multi-model ensemble of regional climate models. Global and Planetary Change 151, 134-143. https://doi.org/10.1016/j.gloplacha.2016.10.008

Segura-Beltran, F., Sanchis-Ibor, C. 2013. Assessment of channel changes in a Mediterranean ephemeral stream since the early twentieth century. The Rambla de Cervera, eastern Spain. Geomorphology 201, 199-214, https://doi.org/10.1016/j.geomorph.2013.06.021

Shannon, J., Richardson, R., Thornes, J. 2002. Modelling event-based fluxes in ephemeral streams. In: L. J. Bull, M. J. Kirkby (Eds.). Dryland Rivers: Hydrology and Geomorpohology of Semi-Arid Channels, 129-172 pag., John Wiley and Sons, Chichester, England.

Skoulikidis, N.T. Sabater, S., Datry, T., Morais, M.M., Buffagni, A., Dörflinger, G., Zoogaris, S., SánchezMontoya, M.M., Bonada, N., Kalogianni, E., Rosado, J., Vardakas, L., De Girolamo, A.M., Tockner, K. 2017. Non-perennial Mediterranean rivers in Europe: status, pressures, and challenges for research and management. Science of the Total Environment 577, 1-8. https://doi.org/10.1016/j.scitotenv.2016.10.147

Snelder, T.H., Datry, T., Lamouroux, N., Larned, S.T., Sauquet, E., Pella, H., Catalogne, C. 2013. Regionalization of patterns of flow intermittence from gauging station records. Hydrol. Earth Syst. Sci. 17, 2685-2699.

Tarolli, P., Borga, M., Morin, E., Delrieu, G. 2012. Analysis of flash flood regimes in the North-Western and South-Eastern Mediterranean regions, Nat. Hazards Earth Syst. Sci. 12, 1255-1265. https://doi.org/10.5194/nhess-12-1255-2012

Témez, J.R. 1978. Cálculo hidrometeorológico de caudales máximos en pequeñas cuencas naturales. Dir. General de Carreteras, Serv. de Publ., Madrid.

Valdes-Abellan, J., Pardo, M.A., Tenza-Abril, A.J. 2017. Observed precipitation trend changes in the western Mediterranean region. International Journal of Climatology 37, 1285-1296. https://doi.org/10.1002/joc.4984

Wainwright, J., Turnbull, L., Ibrahim, T.G., Lexartza-Artza, I., Thornton, S.F., Brazier, R. 2011. Linking environmental regimes, space and time: interpretations of structural and functional connectivity. Geomorphology 126, 387-404. https://doi.org/10.1016/j.geomorph.2010.07.027

Wolman, M.G., Gerson, R. 1978. Relative scales of time and effectiveness of climate in watershed geomorphology. Earth Surface Processes 3, 189-208. https://doi.org/10.1002/esp.3290030207

Xoplaki, E., Trigo, R.M., García-Herrera, R., Barriopedro, D., D’Andrea, F., Fischer, E.M., Gimeno, L., Gouveia, C., Hernández, E., Kuglitsch, F.G., Mariotti, A., Nieto, R., Pinto, J.G., Pozo-Vázquez, D., Saaroni, H., Toreti, A., Trigo, I.F., Vicente-Serrano, S.M., Yiou, P., Ziv, B. 2012. 6-Large-Scale Atmospheric Circulation Driving Extreme Climate Events in the Mediterranean and its Related Impacts. The Climate of the Mediterranean Region. Elsevier, 347-417. https://doi.org/10.1016/B978-0-12-416042-2.00006-9

Yair, A., Kossovosky, A. 2002. Climate and surface properties: hydrological response of small arid and semi-arid watersheds. Geomorphology 42, 43-57. https://doi.org/10.1016/S0169-555X(01)00072-1

Yair, A., Raz-Yassif, N. 2004. Hydrological processes in a small arid catchment: scale effects of rainfall and slope length. Geomorphology 61, 155-169. https://doi.org/10.1016/j.geomorph.2003.12.003

Zoccatelli, D., Borga1, M., Viglione, A., Chirico, G.B., Blöschl, G. 2011. Spatial moments of catchment rainfall: rainfall spatial organisation, basin morphology, and flood response. Hydrol. Earth Syst. Sci. 15, 37673783. https://doi.org/10.5194/hess-15-3767-2011

Zoccatelli, D., Marra, F., Armon, M., Rinat, Y., Smith, J.A., Morin, E. 2019. Contrasting rainfall-runoff characteristics of floods in desert and Mediterranean basins. Hydrol. Earth Syst. Sci. 23, 2665-2678; https://doi.org/10.5194/hess-23-2665-2019 